\title{
Larangan Menimbun Dan Monopoli
}

\author{
Arohman \\ Jurusan IImu Hadis UIN Sultan Maulana Hasanudin Banten \\ Arohmanalalfauzi@gmail.com
}

\begin{abstract}
Abstrak
Hoarding / monopolizing is the act of storing assets, benefits or services and being reluctant to sell and give them to others, which results in drastic increases in market prices due to limited supplies or completely missing stock of goods from the market, while people need the benefits of these products. Essentially the definition above is the same, and it can be understood that an intention or monopoly is buying goods when the price is high, storing the goods so that they are less stocked in the market, the lack of supply of goods makes demand rise and prices also rise, hoarders sell the goods they hold when they reject them., hoarding goods causes the market mechanism to break down.
\end{abstract}

Key words: Hoarding and Monopoly

\begin{abstract}
Absrtak
Menimbun / memonopoli adalah tindakan menyimpan harta, manfaat atau jasa dan enggan menjual dan memberikannya kepada orang lain, yang mengakibatkan melonjaknya harga pasar secara drastis disebabkan persediaan terbatas atau stok barang hilang sama sekali dari pasar, sedangkan masyarakat memerlukan manfaat dari produk tersebut.

Secara esensi definisi di atas sama, dan dapat difahami bahwa iktikar atau monopoli yaitu membeli barang ketika harga mahal, menyimpan barang tersebut sehingga kurang persediaannya di pasar, kurangnya persediaan barang membuat permintaan naik dan harga juga naik, penimbun menjual barang yang di tahannya ketika telah menjolak, penimbun barang menyebabkan rusaknya mekanisme pasar.
\end{abstract}


Kata kunci : Menimbun dan Monopoli

\section{Pendahuluan}

Pada kenyataannya, berbagai aktivitas ekonomi adalah dinamika yang dipengaruhi banyak hal.Pengaruh itu dapat berupa unsuryang berasal dari ekonomi itu sendiri seperti mencari keuntungan, atau pengaruh sosial maupun politik. Hal-hal ini kemudian memunculkan dinamika perdagangan yang kurang mempertimbangkan etika ekonomi dan sosial.pelanggaranpelanggaran bahkan dilakukan. Pelanggaran-pelanggaran yang dimaksud dilakukan dengan banyak cara, antara lain dengan cara melakukan penimpunan, pemaksaan, atau penahanan (penimbunan) barang dagangan atau pada tingkat yang lebih luas monopoli pasar.semua itu dilakukan untuk menunjukan kekuasaan dan penguasaan terhadap perdagangan atau pasar karena berbagai alasan yang disebutkan tadi.

Menimbun dan memonopoli adalah tindakan menyimpan harta, manfaat atau jasa dan enggan menjual dan memberikannya kepada orang lain, sehingga mengakibatkan melonjaknya harga pasar secara drastis karena disebabkan persediaan terbatas atau stok barang hilang sama sekali dari pasar. Sedangkan masyarakat memerlukan produk, manfaat, atau jasa tersebut.

Para ulama berbeda pendapat tentang hukum monopoli (ihtikar), dengan perincian sebagai berikut:

1. Haram secara mutlak (tidak dikhususkan bahan makanan saja), hal ini di dasari oleh sabda Nabi SAW:

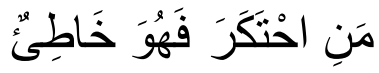

Artinya: "Barangsiapa menimbun maka dia telah berbuat dosa".

(HR. Muslim 1605).

2. Makruh secara mutlak, dengan alasan bahwa larangan Nabi SAW berkaitan dengan ihtikar adalah terbatas kepada hukum makruh saja, lantaran hanya sebagai peringatan bagi umatnya. 
3. Haram apabila berupa bahan makanan saja, adapun selain bahan makanan, maka dibolehkan, dengan alasan hadits riwayat Muslim di atas, dengan melanjutkan riwayat tersebut yang dhohirnya membolehkan ihtikar selain bahan makanan, sebagaimana riwayat lengkapnya, ketika Nabi SAW bersabda:

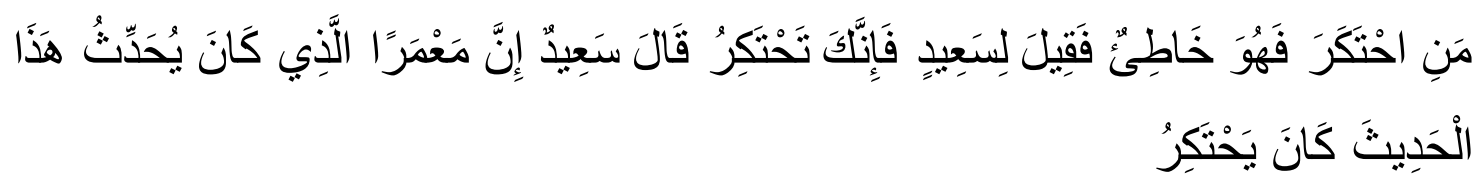

Artinya: "Barangsiapa menimbun maka dia telah berbuat dosa. Lalu Sa'id ditanya, "Kenapa engkau lakukan ihtikar?" Sa'id menjawab, "Sesungguhnya Ma'mar yang meriwayatkan hadits ini telah melakukan ihtikar!' (HR. Muslim 1605).

Imam Ibnu Abdil Bar mengatakan: "Kedua orang ini (Said bin Musayyab dan Ma'mar (perowi hadits) hanya menyimpan minyak, karena keduanya memahami bahwa yang dilarang adalah khusus bahan makanan ketika sangat dibutuhkan saja, dan tidak mungkin bagi seorang sahabat mulia yang merowikan hadits dari Nabi SAW dan seorang tabi'in (mulia) yang bernama Said bin Musayyab, setelah mereka meriwayatkan hadits larangan ihtikar lalu mereka menyelisihinya (ini menunjukkan bahwa yang dilarang hanyalah bahan makanan saja).

4. Haram ihtikar disebagian tempat saja.

Seperti di kota Makkah dan Madinah, sedangkan tempat-tempat lainnya, maka dibolehkan ihtikar di dalamnya, hal ini lantaran Makkah dan Madinah adalah dua kota yang terbatas lingkupnya, sehingga apabila ada yang melakukan ihtikar salah satu barang kebutuhan manusia, maka perekonomian mereka akan terganggu dan mereka akan kesulitan mendapatkan barang yang dibutuhkan, sedangkan tempat-tempat lain yang luas, apabila ada yang menimbun barang dagangannya, maka biasanya tidak mempengaruhi perekonomian manusia, sehingga tidak dilarang ihtikar di dalamnya.

5. Boleh ihtikar secara mutlak.

Mereka menjadikan hadits-hadits Nabi SAW yang memerintahkan orang yang membeli bahan makanan untuk membawanya ke tempat tinggalnya terlebih dahulu sebelum menjualnya kembali sebagai dalil dibolehkahnya ihtikar, seperti dalam hadits:

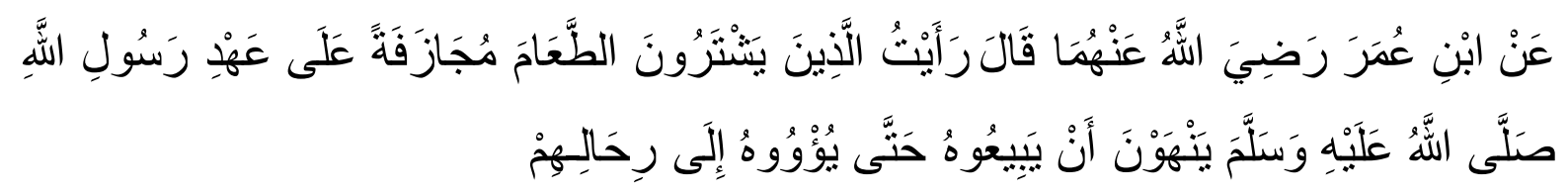


Artinya: "Dari Ibnu Umar r.a. beliau berkata: "Aku melihat orang-orang yang membeli bahan makanan dengan tanpa ditimbang pada zaman Rosulullah SAW mereka dilarang menjualnya kecuali harus mengangkutnya ke tempat tinggal mereka terlebih dahulu."

(HR. Bukhori 2131, dan Muslim 5/8).

Secara esensi definisi di atas sama, dan dapat difahami bahwa iktikar yaitu:

1. Membeli barang ketika harga mahal.

2. Menyimpan barang tersebut sehingga kurang persediaannya di pasar.

3. Kurangnya persediaan barang membuat permintaan naik dan harga juga naik.

4. Penimbun menjual barang yang di tahannya ketika harga telah melonjak.

5. Penimbunan barang menyebabkan rusaknya mekanisme pasar.

Larangan Terhadap Tengkulak

Dalam Bulughul Maram. Hadits No. 827 .

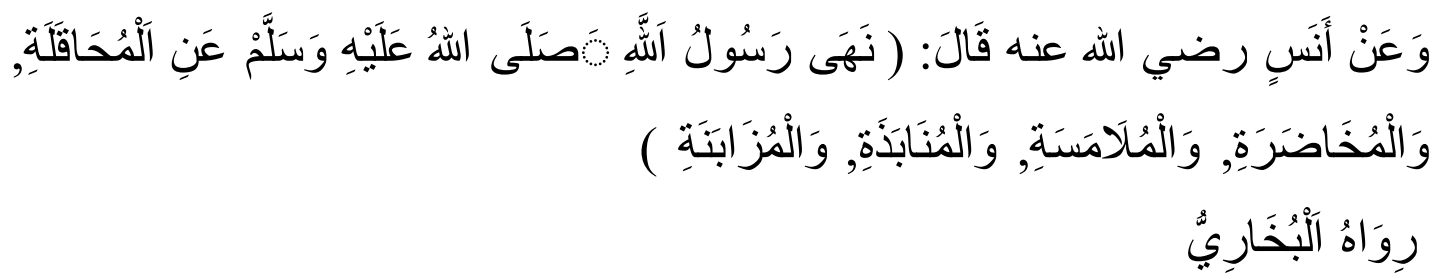

\section{Terjemahan Hadits:}

"Anas berkata: Rasulullah Shallallaahu 'alaihi wa Sallam melarang jual-beli dengan cara muhaqalah, muhadlarah (menjual buah-buahan yang belum masak yang belum tentu bisa dimakan), mulamasah (menjual sesuatu dengan hanya menyentuh), munabadzah (membeli sesuatu dengan sekedar lemparan), dan muzabanah”. Riwayat Bukhari.

\section{Penjelasan Hadits:}

Menjual kurma basah dengan kurma kering dengan takaran (yang sama) dan menjual anggur segar dengan anggur kering (kismis) dengan takaran sama pula. Dalam hadits diatas telah dijelaskan bahwa kelima jenis jual beli tersebut dilarang oleh Rasulullah saw. Karena sistem jual beli tersebut dapat merugikan salah satu pihak. Sebagaimana dalam Shahih Bukhori, hadits nomor 2312 juga dijelaskan mengenai terlarangnya jual beli yang merugikan salah satu pihak, karena didalamnya mengandung riba. Hadits tersebut diriwayatkan oleh Abu Said al Khudriy r.a. 
Bahwa suatu ketika beliau membawa kurma kepada Nabi. Kemudian beliau bertanya mengenai asal usul kurma tersebut, lalu beliau menceritakannya. Bahwa kurma tersebut berasal dari akad jual beli (barter) kurma kering 2 sha' dengan kurma yang baik 1 sha'. Lalu Rosul bersabda "Hati-hati, hati-hati ini riba, ini riba, jangan lakukan. Apa bila kamu ingin membeli kurma yang bagus maka jual terlebuh dahulu kurmamu yang jelek, kemudian hasil penjualanya gunakan untuk membeli kurma yang bagus".

Dr. Nasrun Haroen, MA mengatakan bahwa dalam syariat Islam ditetapkan hak khiyar bagi orang-orang yang melakukan transaksi perdata agar tidak dirugikan dalam transaksi yang mereka lakukan. Dengan demikian ulama' fikih sepakat menyatakan bahwa jual beli yang mengandung unsur penipuan, seperti almulamasah dan almuzabanah adalah tidak sah atau batil. Dengan demikian dapat disimpulkan bahwa dilarangnya lima macam jual beli diatas berhak untuk memilih atau untuk membatalkan penjualan.

Dijelaskan pula hadits mengenai larangan terhadap tengkulak (BM:1412)

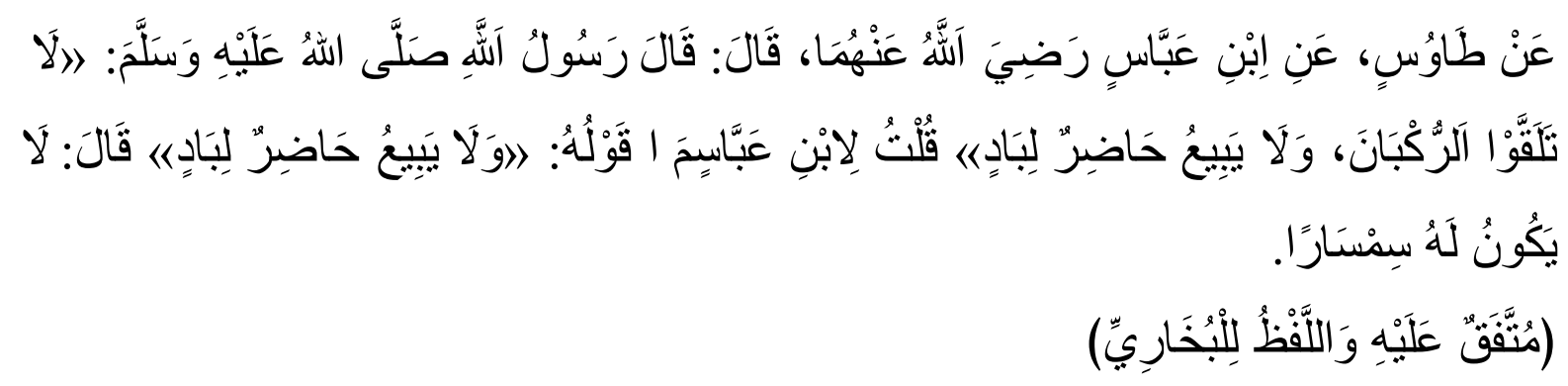

\section{Terjemahan Hadits:}

"Dari thawus dari Ibnu abbas ia berkata: telah bersabda Rasulullah SAW: " Janganlah kamu mencegat kafilah-kafilah dan janganlah orang-orang kota menjual buat orang desa."Saya bertanya kepada Ibnu abbas, " Apa arti sabdanya.? "Janganlah kamu mencegat kafilah-kafilah dan jangan orang-orang kota menjualkan buat orang desa," Ia menjawab: "Artinya janganlah ia menjadi perantara baginya." (Muttafaq alaih, tetapi lafazh tersebut dari Bukhari).

\section{Tinjauan Bahasa :}

تَلَقُّ $\quad$ Mencegat. Maksudnya pergi menjumpai kafilah sebelum mereka sampai dikota dan sebelum mereka mengetahui harga pasar. 


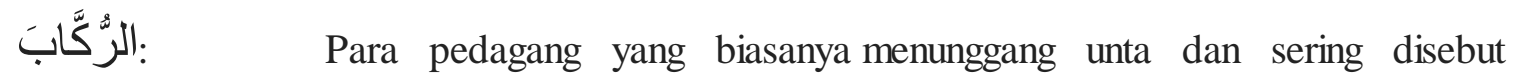
kafilah.

$$
\text { : Makelar }
$$

\section{Penjelasan Hadits:}

Diantra kebiasaan masyarakat Arab adalah berdagang ke Negara tetangga. Dari Mekkah mereka membawa barang-barang hasil produk Mekkah untuk dijual ke Negara lain kemudian pulangnya mereka membawa barang-barang dari Negara lain yang sangat diperlukan oleh penduduk Mekkah atau kota-kota lainnya di Arab untuk memperdagangkan barang-barang mereka kepada penduduk Mekkah. Biasanya para pedagang tersebut berangkat bersama-sama dalam satu rombongan besar yang disebut kafilah.

Sebenarnya para kafilah tersebut sudah terbiasa behenti dipasar atau ditempat berkumpulnya penduduk. Harga barang yang dibawa oleh rombongan dalam kafilah ini tentu saja murah karena mereka merupakan pedagang pertama. Akan tetapi, penduduk seringkali tidak mendapatkan barang secara langsung dari tangan kafilah karena barang-barang tersebut telah dicegat lebih dulu oleh para tengkulak atau makelar. Mereka memanfaatkan kesempatan tersebut untuk menapatkan keuntungan besar, dengan cara menjual barang yang mereka beli dengan harga lebih tinggi kepada penduduk yang tidak dapat membeli langsung dari kafialah.

Dengan demikian, kafilah pun tidak dapat lagi datang kepasar atau ke tempat-tempat yang biasa dipakai untuk berjual beli dengan penduduk desa karena barangnya habis atau penduduk desa sudah membeli barang dari para tengkulak, dengan harga yang cukup tinggi. Keadaan tersebut sangat memadaratkan, baik bagi para kafilah para penjual dipasar, maupun bagi para penduduk. Oleh karena itu, perbuatan tersebut dilarang.

Sebenarnya hadits diatas mengandung dua larangan:

1. Larangan mencegat para kafilah

Maksud para kafilah disini, baik sendirian ataupun dalam rombongan banyak, baik memakai kendaraan ataupun berjalan. Akan tetapi, biasanya kafilah datang dengan rombongan besar dan mengendarai unta. Tempat yang dilarang mencegat barang adalah diluar pasar, atau diluar tempat menjual barang. 
Menurut Hadawiyah dan Asy-syafi'I melarang mencegat barang diluar daerah, alasannya adalah karena penipuan kepada kafilah, sebab kafilah belum mengetahui harganya. Malikiyah, Ahmad, dan Ishaq berpendapat bahwa mencegat para kafilah itu dilarang, sesuai dengan zahir hadits. Hanafiyah dan Al-Auja'i membolehkan mencegat kafilah jika tidak mendatangkan mudarat kepada penduduk.

\section{Larangan menjadi perantara}

Perantara merupakan penafsiran Ibnu Abbas dari kata hadiru libad, yakni penduduk kota menjadi perantara bagi penduduk desa.

Tujuan para tengkulak dari kota menjadi perantara untuk mengambil keuntungan sebanyak-bayaknya. Merka membohongi penduduk desa dengan menjual barang dengan harga sangat tinggi sesuai keinginan mereka. Perbuatan tersebut tentu saja dilarang oleh islam karena sangat memadaratkan.

Berbeda hukumnya bila perantara betul-betul berusaha menolong penduduk yang tidak dapat membeli langsung dari pasar atau dari para kafilah. Barang-barang tersebut tidak akan sampai ketangan penduduk jika tidak melalui tengkulak (perantara). Perantara seperti itu dibolehkan, bahkan ia menjadi penolong bagi orang-orang yang tidak mampu kekota untuk pergi membeli barang. Akan tetapi harganya jangan sampai mencekik penduduk. Lebih baik jika tidak mengambil keuntungan ia hanya mengambil keuntungan sedikit atau sekedarnya saja. Perantara seperti itu dikategorikan sebagai pedagang yang diperbolehkan dalam Islam, bahkan kalau jujur dan bersih, mereka telah melakukan pekerjaan yang paling baik.

Dengan demikian, yang menjadi landasan tentang larangan untuk menjadi perantara adalah adanya kemadaratan bagi penduduk, sedangkan jika menimbulkan kemaslahatan bagi penduduk hal itu diperbolehkan, bahkan dianjurkan. Telah dijelaskan pula bahwa islam mensyari'atkan penjual dan pembeli agar tidak tergesa-gesa dalam bertransaksi, sebab akan menimbulkan penyesalan atau kekecewaan. Islam mensyari'atkan tidak hanya ada ijab kabul dalam jual beli, tapi juga kesempatan untuk berpikir pada pihak kedua selama mereka masih dalam satu majlis.

Menimbun yang diharamkan menurut kebanyakan ulama fikih bila memenuhi tiga kriteria: 
a. Barang yang ditimbun melebihi kebutuhannya dan kebutuhan keluarga untuk masa satu tahun penuh. Kita hanya boleh menyimpan barang untuk keperluan kurang dari satu tahun sebagaimana pernah dilakukan Rasulullah SAW.

b. Menimbun untuk dijual, kemudian pada waktu harganya membumbung tinggi dan kebutuhan rakyat sudah mendesak baru dijual sehingga terpaksa rakyat membelinya dengan harga mahal.

c. Yang ditimbun (dimonopoli) ialah kebutuhan pokok rakyat seperti pangan, sandang dan lain-lain.

Dalam Bulughul Maram. Hadits No. 833

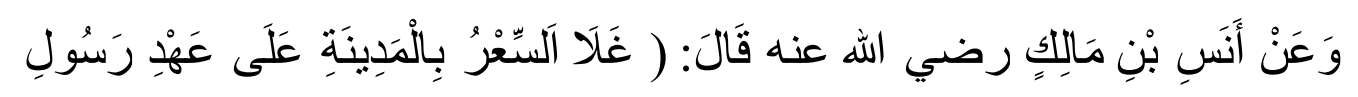

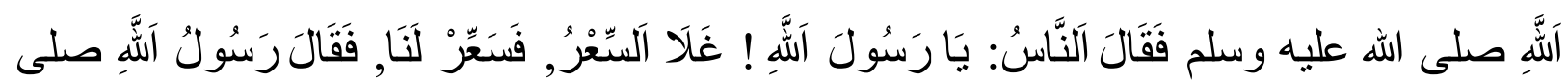

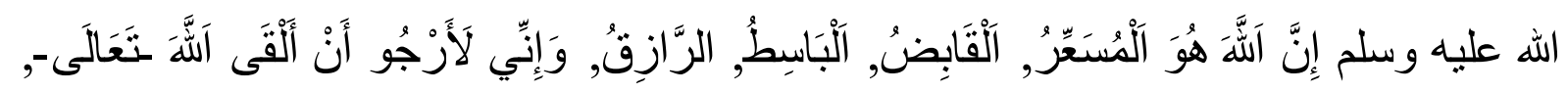

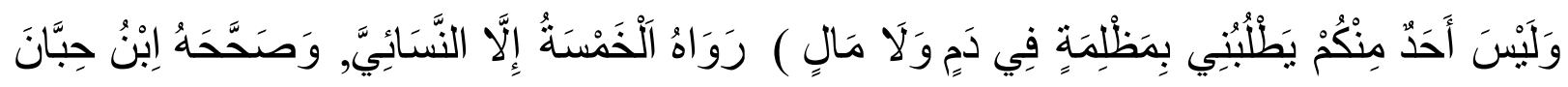

\section{Terjemahan Hadits:}

Anas Ibnu Malik berkata: Pada zaman Rasulullah Shallallaahu 'alaihi wa Sallam pernah terjadi kenaikan harga barang-barang di Madinah. Maka orang-orang berkata: Wahai Rasulullah, harga barang-barang melonjak tingi, tentukanlah harga bagi kami. Lalu Rasulullah Shallallaahu 'alaihi wa Sallam bersabda: "Sesungguhnya Allah lah penentu harga, Dialah yang menahan, melepas dan pemberi rizki. Dan aku berharap menemui Allah dan berharap tiada seorangpun yang menuntutku karena kasus penganiayaan terhadap darah maupun harta benda." Riwayat Imam Lima kecuali Nasa'i. Hadits shahih menurut Ibnu Hibban.

Dijelaskan pula pada Hadits Riwayah Muslim mengenai larangan menimbun barang pokok:

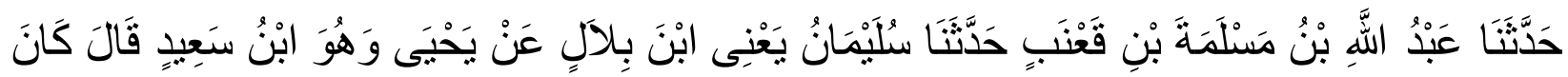

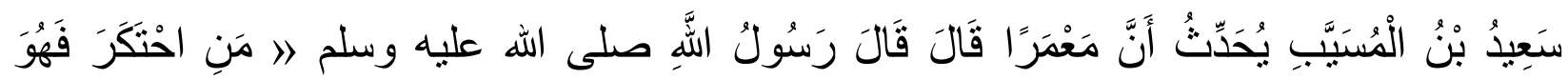




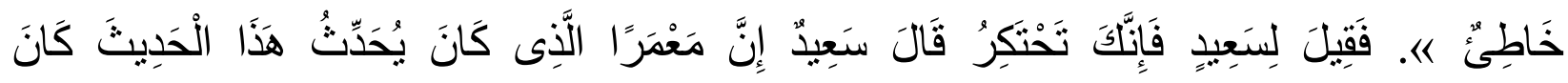 بَحْنَكِرْ.(رواه مسلم)}

\section{Terjemahan Hadits:}

Diceritakan dari Abdullah bin Maslamah bin Qa'nab, diceritakan dari Sulaiman bin Bilal, dari Yahya bin Sa'id berkata; Sa'id bin Musayyab menceritakan bahwa sesungguhnya Ma'mar berkata; Rasulullah saw pernah bersabda : Barang siapa yang melakukan praktek ihtikar (monopoli) maka dia adalah seseorang yang berdosa. Kemudian dikatakan kepada Sa'id, maka sesungguhnya kamu telah melakukan ihtikar, Sa'id berkata; sesungguhnya Ma'mar yang meriwayatkan hadits ini ia juga melakukan ihtikar. (HR. Muslim)

\section{Penjelasan Hadits :}

Dalam riwayat yang lain disebutkan menggunakan lafadz : لَّحْتَكِ خَاطِئ dafadz hَاطِئ dalam hadits diatas menurut ahli bahasa memiliki arti seseorang yang berbuat durhaka dan melakukan perbuatan dosa.

Berdasarkan keterangan dalam kitab Badrul Munir, mengutip yang disampaikan oleh Abu Mas'ud Al-Dimasyqi dari riwayat Ibnu Musayyab menyebutkan, bahwa yang dilakukan oleh Sa'id adalah melakukan penahanan atas barang berupa minyak. Sedangkan menurut Tirmidzi, Sa'id bin Musayyab hanya melakukan penahanan atas beberapa komoditas yakni minyak, biji gandum dan sejenisnya saja. Sedangkan menurut Abu Daud yang dilakukan Sa'id adalah melakukan praktek ihtikar atas biji kurma, benang dan rempah-rempah. Sedangkan menurut Ibnu Abdul Bar beliau menuturkan bahwa Sa'id dan Ma'mar keduanya melakukan ihtikar atas minyak saja. Dan mereka berdua beranggapan yang dimaksudkan dalam hadits tersebut adalah melakukan penahanan atas barang-barang yang menjadi kebutuhan pokok saja, bukan komoditas lain seperti minyak, biji kurma, rempah-rempah serta komoditas lain yang bukan merupakan kebutuhan pokok.

Para ulama membagi monopoli kedalam dua jenis:

a. Monopoli yang haram, yaitu monopoli pada makanan pokok masyarakat, Sabda Rasulullah, riwayat Al-Asram dari Abu Umamah:

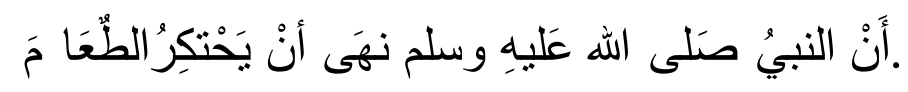


Artinya:

"Nabi SAW melarang monopoli makanan" Jenis inilah yang dimaksud dalam hadis bahwa pelakunya bersalah, maksudnya bermaksiat, dosa dan melakukan kesalahan.

b. Monopoli yang diperbolehkkan, yaitu pada suatu yang bukan kepentingan umum, seperti: minyak, lauk pauk, madu, pakaian, hewan ternak, pakan hewan.

Sehubungan dengan celaan melakukan penimbunan ini, telah disebutkan sejumlah hadis diantaranya:

- Hadits Umara dari Nabi SAW

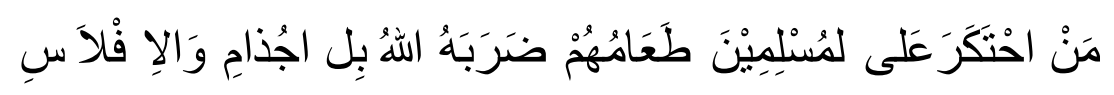

Artinya:

"Siapa menimbun makanan kaum muslimin, niscaya Allah akan menimpakan penyakit dan kebangkrutan kepadanya."

- Diriwayatkan Ibnu Majah dengan Sanad Hasan

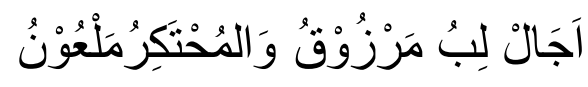

Artinya :

"orang yang mendatangkan barang akan diberi rezeki dan orang yang menimbun akan dilaknat"

Kesimpulan

Nash-nash yang ada, yang bersifat umum maupun khusus, melarang penimbunan harta dengan cara apapun. Jenis harta yang ditimbun tidak terbatas pada barang apapun, tidak terbatas pada makananatau kebutukan pokok saja bila barang-barang itu telah menjadi kebutuhan manusia dan bila penimbunnya menimbulkan kemedaratan bagi manusia, maka ia masuk katagori ihtikar

Al-Quran yang memuat nilai-nilai universal maupun hadis yang menjelaskan tentan ihtikar masih relevan untuk dikaji dan selalu actual untuk menjelaskan kondisi dan problema perekonomia umat sepanjang masa. Hal itu sejalan dengan ajaran islam yang sesuai dengan kondisi zaman dan makan. Islam selalu relevan dengan masa dan tempat kapanpun dan dimanapun. 
Menimbun / memonopoli adalah tindakan menyimpan harta, manfaat atau jasa dan enggan menjual dan memberikannya kepada orang lain, yang mengakibatkan melonjaknya harga pasar secara drastis disebabkan persediaan terbatas atau stok barang hilang sama sekali dari pasar, sedangkan masyarakat memerlukan manfaat dari produk tersebut.

Secara esensi definisi di atas sama, dan dapat difahami bahwa iktikar atau monopoli yaitu:

1. Membeli barang ketika harga mahal.

2. Menyimpan barang tersebut sehingga kurang persediaannya di pasar.

3. Kurangnya persediaan barang membuat permintaan naik dan harga juga naik.

4. Penimbun menjual barang yang di tahannya ketika harga telah melonjak.

5. Penimbunan barang menyebabkan rusaknya mekanisme

\section{DAFTAR PUSTAKA}

Al-Asqalani Ibn Hajar, Panduan Lengkap Masalah-Masalah Fiqih, Akhlak dan Keutamaan Amal. Bandung: Mizan Pustaka, 2010.

Rachmat Syafe'I. Al-Hadits Aqidah,Akhlaq, Sosial, Dan Hukum. Bandung: Pustaka Setia, 2000. Salim Abd.Rasyid, Meraih Jalan Petunjuk, Syarah Bulugul Maram 3. Bandung: Nuansa Aulia, 2007.

Salim Abd.Rasyid, Meraih Jalan Petunjuk, Syarah Bulugul Maram. Bandung: Nuansa Aulia, 2007. 